\title{
HOW INDUSTRIAL POLICIES SHAPED THE GLOBALIZATION OF THE CHINESE FILM INDUSTRY SINCE THE 1990S'
}

\author{
Xiaolan Zhou \\ South China Normal University \\ zhxl@hotmail.fr
}

\begin{abstract}
The Chinese film industry experienced more than twenty years of reform that has brought undeniable success, however, it has been confronted by a dilemma in the context of globalization: The "coming in" of foreign films and investments is becoming increasingly convenient and profitable, whereas the "going out" of domestic films stays in a stagnant or even retrogressive situation. This issue results from an essential factor: the government's intervention, as well as its policies. This article endeavors to study the duality of the government's role in the film industry. First, it generally creates a favorable economic environment, which coincides with Stiglitz's judgement about the government's positive function in promoting industries. Marvel films provide us with an example to support this point of view. Second, the inadequacy of the incentive and protective policies denotes the opposite direction taken from the propositions of Michael Porter, who himself is strongly against the direct involvement of the government in the production process, during his demonstration of the diamond model referring to competitive advantages. This paper implies that the government's intervention should be assessed by new paradigms, for the reason that classic theories, with focus on factor conditions, might not be applicable anymore for neither sophisticated industries, like the film industry, nor such an enormous entity as China.
\end{abstract}

\section{Keywords}

competitive advantages; domestic films; film industry; foreign films; government's role; industrial policies

\footnotetext{
About the Author

Xiaolan Zhou is Associate Professor in the School of History and Culture, South China Normal University. Her research interests are economic and social history of France, as well as the industrial history of China.
} 


\section{INTRODUCTION}

In China, with the help of industrial policies, the film industry transitioned from an instrument of propaganda which witnessed the intervention of a pervasive government before the 1990 os to a profitable sector of the economy, thanks in large part to the Reform and Opening-Up policies proposed by Deng Xiaoping. In the context of a market economy, the industry experienced cyclical upheavals, a consequence of the dramatic changes in its role and the inability to adapt to new economic environments. In the mid-1990s, in order to break the local and central patronage that hindered the revival of the industry, a number of policy makers contended to launch reforms in substantial directions.

Most neo-liberal economists credited China's success to the implementation of a market-oriented economy. This article argues that the film industry could not have been introduced to the massive Chinese consumer market without government intervention. However, incentive and protective measures, instead of encouraging the production and enhancing the quality of Chinese films, marred the industry. This duality of government intervention in the process of globalization, which is interpreted in this article as the "coming in" of foreign films and investments as well as the "going out" of domestic films, should be acknowledged.

While the development of the Chinese film industry has not been thoroughly explored, there is a rich body of literature on the role and importance of government intervention in East Asia. Around the 1970s, nascent neo-liberalism opposed various forms of neo-interventionism. In the 1970 os to 1980 , most economists agreed that the free market and limited government intervention contributed to economic growth (e.g. Krueger, Lal, Balassa, Hughes, and others), whereas from the mid-1980s, a large number of experts insisted that government intervention played a key role in the remarkable success exemplified by East Asian states such as Korea, Singapore, and Taiwan (e.g. Stiglitz, Wade, Amsden, Rodrik, Singh, and others). Amongst the latter, Stiglitz stands out as he opened up an overall perspective for the theoretization of the government's role in industrial growth based on the experiences of Singapore, Korea, and Taiwan by elucidating that politics and political decisions could be very influential in stimulating and directing most industries. Beyond those classic interpretations concerning the government and the market, we count Michael Porter for his neutral position and his conception of the diamond model emphasizing the productivity of firms or nations based on the analysis of competitive advantage. Neo-interventionist propositions were becoming popular because of their interpretation about the extraordinary success of certain industrialized East Asian countries. However, their arguments still need to be justified by presenting more case studies, including the developmental trajectory of Chinese industries. This article thus intends to 
draw attention on the Chinese film industry in order to make three contributions: First, it will study the industry through a historical approach and justify neointerventionists' conclusions by tracing how the Chinese government learned and reacted to overcome the various issues that hindered the growth and globalization of this specific industry. Second, it will depict an image on how policies facilitated the profitability of foreign films, exemplified by the series of Marvel films that have been very well-received in China, in the context of Stiglitz's points of view, to survey the globalization process in this industry. Finally, it will examine the weak export of Chinese films by engaging Porter's theory to explain why incentive and protective policies weakened the globalization trend.

\section{RATIONALE}

This paper, applying Joseph Stiglitz's analytical framework and Michael Porter's diamond model, intends to assess the policies concerning the globalized film industry. As one of the advocates of neo-interventionism, Stiglitz considers the government to be indispensable in the economic growth, particularly in the miraculous growth of East Asian countries during the 199os. The role that the government played in accumulating physical and human capital is defined by different metaphors: engine, catalyst, adaptive systems, equilibrium systems. These metaphors are embedded in Stiglitz's hypothesis that inclines towards none of the extreme cases-neither totally free markets nor absolute planned economies, but mixed economies that allow the government to play a role in the market effectively.

The examination of the government's efficiency in this term was once attached to the model established by Arrow and Debreu in 1954 that specifies how market failure happens if certain conditions are not satisfied. However, this paradigm assumes that information and technology are well-spread and shared in a perfect market. Stiglitz regarded this as a flaw in their theoretical construction, and pointed out that in most cases information and technology asymmetry necessitates government's intervention. In spite of the side effects of government intervention that may eliminate markets and aggravate inequality, with respect to capital and resource allocation in certain developing countries, late industrialized East Asian governments used and promoted markets instead of replacing them. This is the key to their success in the 1990s. For Stiglitz, the government has at least four main functions: 1) It ensures macroeconomic stability; 2) By regulating financial markets, it makes the market function more efficiently; 3) It helps direct investment; and 4) It creates an atmosphere conducive to private investment and ensures political stability. In other words, synergy between governments and markets led to the success of some East Asian countries. More specifically, governments react in the 
following situations: weak markets, technological scarcity, coordination failure, and strategic negotiations with foreign counterparts. Stiglitz's synthesis gives us certain substantial paths to assess the policies on the Chinese film industry that has been engaged to some extent in the similar trajectory of the industrial success of Japan, Korea, and Taiwan. Additionally, Michael Porter's diamond model of national competitive advantage may be useful to assess the achievements realized by the government as well as clarifying the flaws resulting from such policies, that are supposed to support industries, as incentive and protective policies. This topic has been ignored in Stiglitz's work but stays unavoidable when it refers to a statecontrolled industry like the Chinese film industry. Porter's theory, which would be useful tu supplement the former's conception, presents four conventional and non-conventional elements affecting industrial competitive advantages: 1) factor conditions; 2) demand conditions; 3) firm strategy, structure and rivalry; and 4) related and supporting industries. As catalyst and challenger of domestic industries (in this respect, he shares the same opinion as Stiglitz), the government should stimulate companies to yield competitive advantages instead of "involving itself directly in the process."

\section{HOW DID THE INDUSTRIAL POLICIES HELP PROMOTE THE FILM INDUSTRY AND ITS GLOBALIZATION?}

The Chinese film industry started its reforms in 1994. This was a transitional period from a "propaganda" sector to a "manufacturing" sector capable of making profits and entertaining the public. Unlike the experience of South Korea, ${ }^{2}$ the Chinese film industry needed "political revision" from the hierarchical administrative configuration inside the government at the very beginning of the reform, with the main objective of motivating film practitioners by means of sweeping administrative obstacles (often set up by local authorities). The direct communication between high-ranking cadres in oligopolistic companies and decision-makers seemed to clarify the real problem of stagnation of this industry, completely cut off from the market, and thus they reached a unanimous decision to activate the market.

\section{A. Communication between Industrial Practitioners and Decision-makers Leads to Institutional Reforms}

In the 1990s, Deng Xiaoping's "Reform and Open-up Policy" was aimed at remodeling most of the industries. However, the film industry still remained in 
a very difficult situation. Certain national studios closed, distribution divisions were in deficit, the cinemas were often empty, and film equipment were aging. The government reclassified the film industry as part of the "manufacturing" sector and decided to take actions for rationalizing a system that was once confined in a planned economy. This part endeavors primarily to trace the institutions in charge of production, distribution and screening in a historical approach aimed at shedding light on how the government enhanced the institutional efficiency to meet the domestic market mechanism.

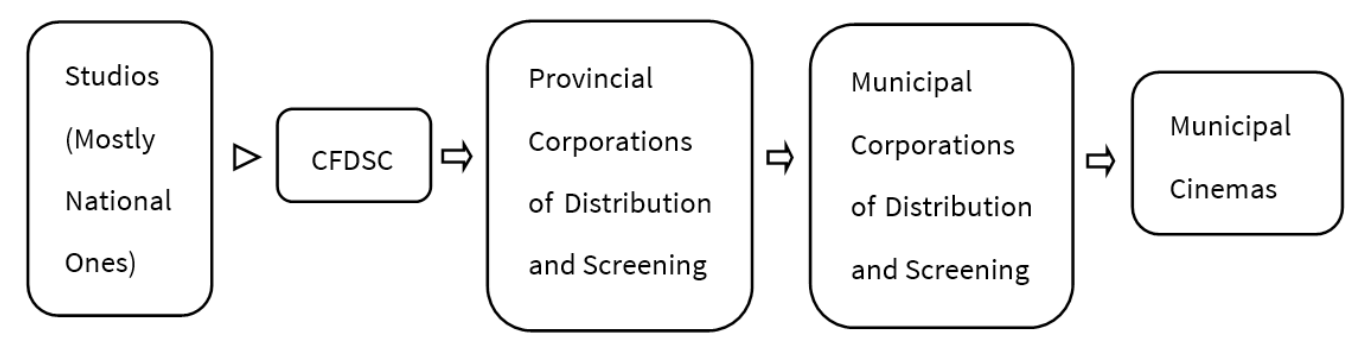

Figure 1: The Production-Distribution-Screening Process before the Reforms

Soon after the foundation of the People's Republic of China in 1949, the film industry was made a division of the propaganda system and was put under the direct control of the China Film Distribution and Screening Corporation (CFDSC) which was an official representative of the governmental administration founded in 1958. Fig.1 indicates that films had to face at least three levels of censorship from the government and the studios had to share the profits earned, leaving little space for productivity and creativity in the process of filmmaking, which, to a certain extent, resulted in a reduction of the output in the film industry until the 198 os. Moreover, the filmmakers would only receive a paltry $10 \%$ of the profit, which was not motivating for Chinese agents, and the other $90 \%$ would go to the China Film Distribution and Screening Corporation and to the provincial and municipal culture departments. The import and distribution of foreign films also reflect the rigidity of the system. From 1949 to 1994, a small number of foreign films was imported into China, earning a minuscule US\$20,00o per year. As a result, mediocre films that gathered small audiences flooded the market. The turning point happened when new policies were made and put into practice. By the end of 1992, more than twenty meetings took place in order to discuss what could be the best way to rejuvenate the system. On the $5^{\text {th }}$ of January 1993, the Department of Film and Television Broadcasting published document $\mathrm{No}^{\circ} 3{ }^{3}$ stating "Some advice about deepening the actual reform of the film system." The most remarkable 
points in this document are the following: first, the removal of the price cap of the entrance fee to the cinema, and, second, the right for the filmmakers to distribute their films themselves (the distribution of imported films was still under control of the CFDSC). Then came the reforms concerning the import of foreign films initiated by a high-ranking official responsible of the national enterprise, Wu Mengchen (former manager of China Film Group Corporation). Wu suggested the import of foreign films with potential to activate the market and make profits. This bold trial was approved by decision-makers of the State Administration of Radio Film and Television and it began to change the extremely stagnant industry. At the end of 1994, foreign films were immediately imported to China following the "Hollywoodian way" of sharing revenue. Industrial policies sketching the guidelines of the reforms saw the government, in communication with high-ranking agents of the industry, break up most of the local administrative monopoly. However, the government kept a central control over the industry. This strong administrative force remained the key to overcome coordination failure and conflicts between different levels of authorities, especially when the local authorities were deprived of benefits once films were distributed and screened.

\section{B. The Government Introduces Competition into the Market}

For most neo-interventionists, Adam Smith's theory of the invisible hands never worked in a context where information and technology are never shared perfectly among either private or public sectors. Following the policies on administrative improvement, reforms continued to reshape the market which had been weak or even non-existent for around fifty years, not because of the failure of the market, but due to suppression of the market by the government (Stiglitz, "Some Lessons" 158). Once the policy makers decided to reform the whole system by recreating a new and motivating market, they deviated promptly from the old orbit and led the film industry to a lucrative sector that not only encouraged the production of films but also gave a go-ahead signal to foreign films.

The experience began with the entrance of the first Hollywood revenue-sharing film The Fugitive (1993). Imported to China in 1995, it triggered, to some extent, the Chinese film practitioners' ambition by showing the lucrative side of the film industry and demonstrated the potential of the colossal Chinese market with its US\$ 4. million of box office receipts. The domestic market then experienced even more dramatic changes when the box office receipts of films from Hollywood, France, Taiwan and Hong Kong, such as The Shawshank Redemption, The Lion King, Léon, Eat Drink Man Woman, and Chungking Express surprised policy makers as well as the audiences with their propensity to generate profits and their aesthetic value. 
Therefore, since 1995, the import of Hollywood blockbusters has been permitted. The market went through a rebirth, allowing strong competitors to enter the market and forcing their weaker counterparts to improve. This was just the beginning. If the Chinese government was determined to deepen the reforms in all the industries according to the agreements signed with the World Trade Organization (WTO), it had to make further efforts to open up the market. In the case of the film industry, on one hand, films could be produced by various enterprises, either national or private ones and some of them were even given rights of distribution and screening, something that was unimaginable before 1994. On the other hand, the amount of imported films rose from 20 in 1999 to 34 in 2012 and 39 in 2016, most of which realized significant box office receipts in China. In September 2015, after long strategic negotiations with the USA, the Chinese government signed The Cooperative Agreements about the Import and Distribution of Revenue-sharing Films, on the basis of which, the quota for film buyouts would be canceled.

This apparent openness of the film industry remained conditional at its core. The government never really loosened its control on the industry. First, compared to countries such as Korea, Japan, or Singapore, the amount of imported films is rather insignificant. Second, severe censorship still exists in China and all imported films have to be thoroughly examined in order to filter all the scenarios, scenes, conversations that do not align with the government's core values. And finally, the import and distribution of foreign films still lie in the hands of a couple of national enterprises that contribute to a monopoly with both political and economic implications.

\section{The Government Motivates and Coordinates both Domestic and Foreign Film Practitioners}

As Stiglitz once demonstrated, the government is capable of playing the role of coordinator in the market ("Some Lessons" 160). In the case of the Chinese film industry, an omnipresent government with strong powers can intervene when interior coordination between different divisions fails. When the Hollywood blockbuster The Fugitive was shown for the first time in November 1994 in China, it immediately caused tension between the China Film Group Corporation (the only intermediary agency entitled to import and distribute foreign films) and the provincial distribution divisions. This problem was caused by the company's intention to screen the film directly in cinema, avoiding the provincial and municipal distribution divisions. The tension within the administrative framework urged for the suspension of the screening, which would eventually resume several months later, after the policies about deepening the reforms in the film industry 
in 1995 had already been promulgated and justified the activities initiated by the company. Since then, obstacles from the local authorities have been removed.

When dealing with foreign film producers and distributors, the policy makers seemed to break through the stage of "working behind closed doors" and adapted far more vigorous measures. They tried to encourage the Chinese film distributors to go abroad and introduce "good" films (Wang 9). Furthermore, through the increase of the share of the box office, the policy makers endeavored to persuade foreign producers to bring in their best works. It has to be noted that in the $1990 \mathrm{os}$ the revenue generated by Hollywood giants in China was not as impressive as it is today. Take the blockbuster Titanic (1999) as an example: its distributor, $2 \mathrm{O}^{\text {th }}$ Century Fox, received only US\$ 10 million of revenue (Rosen 353) out of the US\$ 56 million generated in the whole country and the rest went to the Chinese distributors and screening sectors. Once aware of the positive effects of foreign films, recognizing the rightness of the policies and of course the pressure from the US government (influenced by the powerful Hollywood companies), the Chinese government yielded in favor of foreign producers and distributors. In February 2012, The Agreement on the Chinese and American Films was finalized: the share of the American producers taken from the total revenue increased from $13 \%$ to $25 \%$ and, in the case of co-produced films, they would receive up to $40 \%$ of the revenue, which favored the profitability of foreign filmmakers and motivated the entrance of their products. The success of Marvel films is an example of this.

\section{DID THESE POLICIES FUNCTION WELL? A CASE STUDY ON MARVEL FILMS IN CHINA}

If all the efforts stated above made the film industry more lucrative and allowed it to flourish, this part will concentrate on outlining how the 18 Marvel films came to China, how they made profit, and how they adapted to the local market.

It is quite clear that the market for foreign and domestic films has been established gradually since 1994. Twenty years of efforts built up a partially free market in which the mechanism of demand (from the audience) and supply (from studios of different backgrounds but closely associated with each other) is relatively wellfunctioning. In other words, the government managed to rebuild a market that motivates the production, distribution, and screening of both domestic and foreign films, a market in which an imported film with a good scenario, famous stars, cutting-edge special effects and outstanding filming techniques is very likely to be well-received in China, a market that has created an environment of mutual benefit for both the audience and the filmmakers. With the signature of the agreement 
of 2012, foreign producers obtained around $25 \%$ (compared to $13.5-17.5 \%$ before the agreement) of the box office, distributors 14.4\% (compared to 21.9-25.9\%), and movie theater chains and cinemas 52.3\% (the same percentage before and after the agreement). This means that even with the rise of the share of foreign producers, their Chinese counterparts are still able to earn most of the profit from imported films, with more than $60 \%$ of the revenue going to them.

When Ironman, the first film produced by Marvel Studios, was introduced in China in 2008 to an audience that was not really familiar with the comic book culture, it lagged behind Kung Fu Panda, oo7 Quantum of Solace, and The Mummy 3 , and thus did not generate the same numbers as it did in other countries where it was released. It received only US\$ 10 million of box office in China compared to US\$ 585 million worldwide. Ten years later, other movies of the Marvel Cinematic Universe not only cultivated the taste of the young generations for this genre of films, making China its second largest market in the world, but also found a particular way to handle all the possible barriers set by the policies of censorship and those limiting foreign capitals. This successful path carved out by the collusion of Marvel Studios, its representative Disney China, the Chinese distributors, and the cinemas and movie theater chains is worth studying.

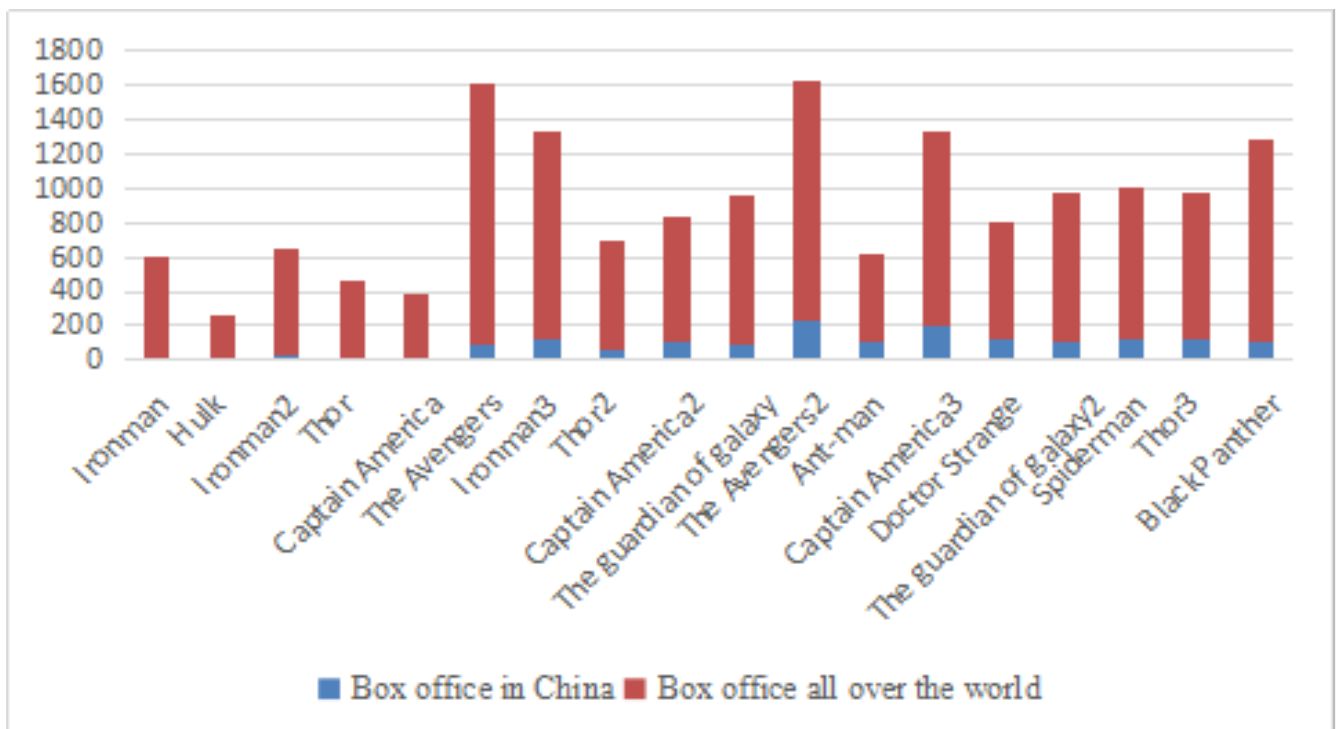

Figure 2: The Box Office of Marvel Films in China and Worldwide (US\$ million) 


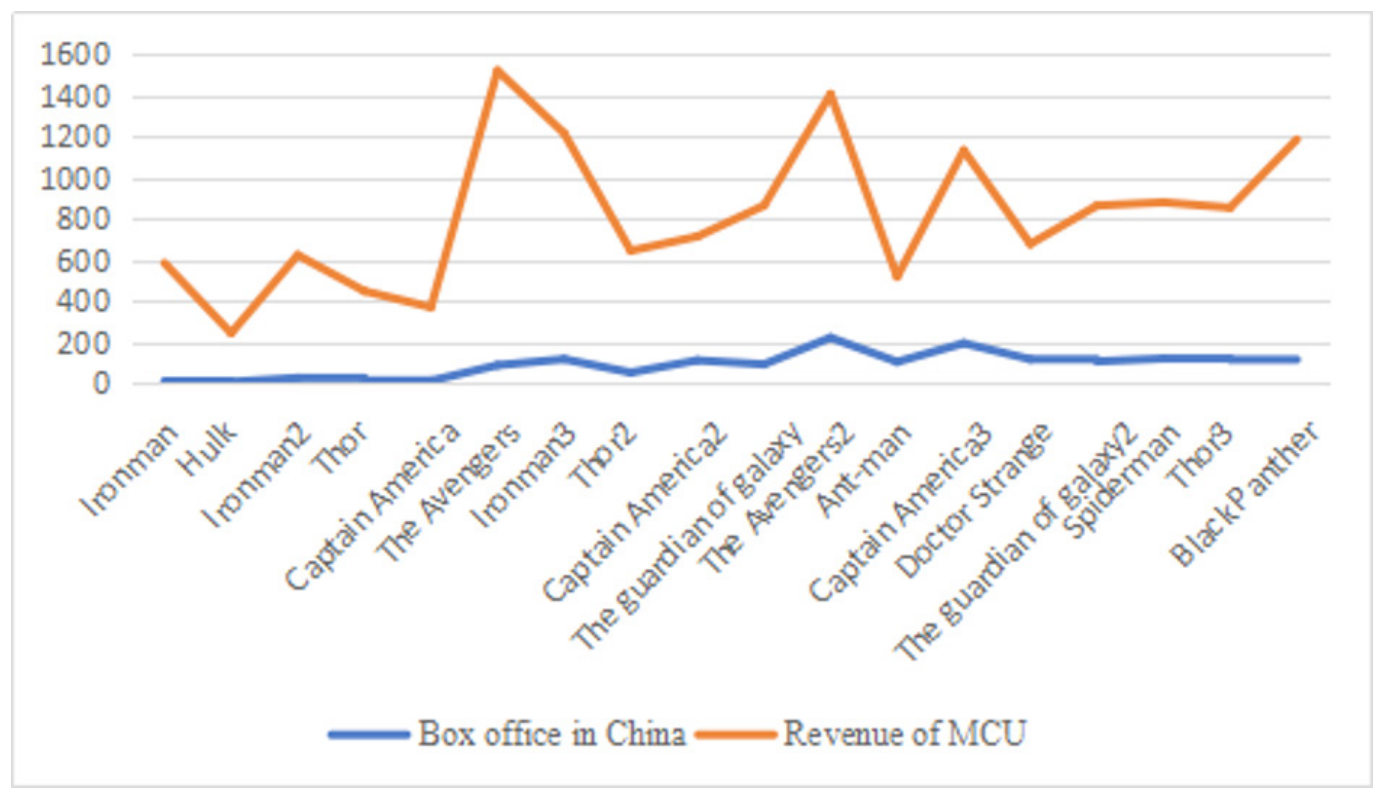

Figure 3: The Box Office of 18 Films of the Marvel Studios and Their Revenue in China (US\$ Million)

The theoretical revenue of Marvel Studios is shown to be close to $13 \%$ of the box office before 2012 and 25\% since the movie The Avengers.

\section{A. More Movie Theater Chains and Cinemas Accelerate the Expansion of the Market}

The satisfying output of Marvel films in China results partially from the process of increasing the number of theater chains (from 34 chains in 2007 to 48 in 2017) that first started in the government-privileged top tiers cities: Beijing, Shanghai, and Guangzhou. It was then gradually extended to the second tier, third tier, and even forth tier cities, allowing for a much denser movie theater network that guarantees better screening channels catering for a wider audience in a larger market. It is noteworthy that construction of movie theater chains depends on a large amount of investment, which rules out the participation of most small and medium-sized private companies but necessitates the government's intervention and organization. 


\section{B. The Government Removed the Restrictions on the Entry of Foreign Companies}

Two important turning points-the deepening of Deng's reform and the entrance of WTO-facilitated the "open door" policies that allowed such foreign movie giants such as The Walt Disney Company, whose business covers production and distribution of films, to install themselves in China. The governmental adherence to the reform and its openness create a more suitable environment for the promotion of Marvel films. The Walt Disney Company Limited, purchasing Marvel Entertainment in 2009 for US\$ 4 billion, was allowed to enter China in 2005 after shifting its business in Asia, from Hong Kong to Shanghai. As a company that has had a long-term relationship with the Chinese government and the Chinese audience, ${ }^{4}$ Walt Disney came to endorse the role of a direct intermediary between the main distributors in China and their audiences.

\section{The Policies Are Paving the Road to Profitability}

Based on the daunting process (due to cultural and ideological differences) that led to the Chinese release of the animated movie Mulan in 1999, Disney adapted its approach and learned to follow the Chinese government's rules and policies. The third instalment of the Ironman series serves as a great example: (1) According to the document $\mathrm{No}_{3}^{\circ}$, a co-production with Chinese film companies would allow the film producer to receive $40 \%$ of the revenue, a rule which led to the decision to include two Chinese actors (Xueqi Wang and Bingbing Fan) in the cast of Ironman 3. Increasing the Chinese participation allowed for more revenue and was meant to show more appreciation from the Chinese audience. (2) The Chinese version of the film even tried to promote the Chinese culture and brands: acupuncture is used to save the life of the superhero, a well-known brand of milk is mentioned by the hero, a port full of cranes from a Chinese national enterprise Zoomlion 中 联重科 is shown, etc. (3) A sign of the mutually beneficial relationship between Disney and the Chinese authority is the fact that some of the negative aspects of the movie, ${ }^{5}$ which might slightly violate the terms of the policies, seem to have been consciously ignored by both parties, so that the huge economic benefits could be realized. (4) To avoid breaching the bottom line of the policies, in most Marvel films, including Ironman 3, violent and bloody scenes are treated skillfully in order to pass the censorship. 


\section{The Fusion of Domestic and Foreign Capital Is Encouraged by the Government}

In the frame of the policies, private capital becomes a non-negligible factor in the film industry. In 2015, the five biggest private companies whose business connects to all three sectors of the film industry-Huayi Brother, Enlight, LETV, Wanda and Bona-contributed $58 \%$ of the total box office (The Association of Film Makers \& the Research Center of the Chinese Film Art Industry 35). With the growing influence of private capitals, some foreign film producers chose to cooperate with these powerful Chinese companies.

The most remarkable case is the integrated unit that included Warner Brothers, DC Comic Inc., Tencent Pictures, and Wanda Pictures. This partnership most likely led to the financial success of the movie Wonder Woman (2017), thanks to Tencent's widespread networks in advertisement and Wanda's large-scale movie theater chains in big cities. From the year 2015, Disney, as well as its subsidiary and partner Marvel Studios, endeavored to seek co-operations with potential Chinese partners and, in July 2015, Disney came to an agreement with NetEase (a portal site with a large community of users in China) aimed at conceiving the first set of Marvel comic books in Chinese. Marvel Studios contracted the promotion of Ironman 3 to DMG, a Chinese company specialized in advertising films, which might have contributed to its US\$ 119 million box office receipts, the highest since the arrival of Marvel films in China.

In the case of the Marvel films, it is obvious that the government in a way created channels through which those films entered China and increased their profitability over the span of ten years. The arrival of foreign investment is meant to offset the uncompetitive part of the domestic industry that is offered a chance to learn from the most productive counterparts abroad, however, the exposure to the international standard of productivity does not always end up with a great success for the whole industry in question.

\section{WHAT DID THE POLICIES FAIL TO DO? THE "GOING OUT" OF THE DOMESTIC FILMS IN DIRE STRAITS}

The increasing import of foreign films has gradually turned China into one of the largest and most profitable markets in the world in which films from Hollywood, Hong Kong, Korea, Japan, France, and others are seeing considerably high turnovers. This, in turn, stimulated the Chinese film practitioners who, being protected (for example, the government sets quotas for the amount of imported 
foreign movies and that of days of screening them) and supported by policies and various enterprises (either national or private), devoted themselves to produce either "main-stream" films, that closely follow the direction set by the government since the existence of the film industry and with the purpose of promoting socialist ideology, or movies of a more "commercial" nature, that adapt to the actual taste of the audience. The government, with the view of guiding the films towards the "political correctness," set up incentive policies.

Such policies as the Special Fund and the 9550 Plan did permit some breakthrough of making "main-stream" films lucrative, however, the financial and critical success of such films remains very much confined to the Chinese domestic market; once exported to foreign markets, these domestic films frequently see mediocre returns, symbolizing the failure of the initiative of diffusing the government's core value on a larger scale.

\section{A. Funds and Protections Are Set Up to Encourage Export-Oriented Production}

On the $9^{\text {th }}$ of January 1991, the Department of Film and Television Broadcasting issued an "Announcement on the Definition of the Entrance Fee Management and the Establishment of the Special Fund" which is still in practice today. All the studios authorized by the State Department, the state-owned distributing and screening corporations and also the state-owned cinemas have the right to apply for this fund. Five years later (in 1996), the government decided, by publishing the 9550 Plan, to produce ten films every year for the duration of the ninth FiveYear Plan. Its main purpose was the gathering of financial support; according to the "Regulations on the application and the management of the special fund of the national film industry" published the same year, $5 \%$ of the revenue accumulated by all the films (domestic or imported ones) must be taxed to support the "cause" of the development of the domestic film industry, ${ }^{6}$ thus keeping national studios and distributors financially supported.

The main purpose for setting up the Special Fund was in fact to force the "mainstream" movie industry to "help itself out" (Zhou 100). More specifically speaking, the fund was set to support the development of the film industry, including the screening of national films, the construction of cinemas, and the translation of films produced by national ethnic minority groups. Besides, SAPPRFT founded

The China Film Promotion International in 2006, especially for the promotion of Chinese films in international festivals and arranging "Beijing Projection" 北京放 映, a fair that aims at selling Chinese domestic films. Available data shows that 
the government injected an increasing amount of financial support to the cause. According to the statistics below, from 2012 to 2018, the amount of financial aid has been increased nine-fold, from about US\$ 7 million to US\$ 51 million.

Table 1: The Special Fund Used Every Year from 2012 (US\$ Million)

\begin{tabular}{lccccccc} 
& $\mathbf{2 0 1 2}$ & $\mathbf{2 0 1 3}$ & $\mathbf{2 0 1 4}$ & $\mathbf{2 0 1 5}$ & $\mathbf{2 0 1 6}$ & $\mathbf{2 0 1 7}$ & $\mathbf{2 0 1 8}$ \\
\hline $\begin{array}{l}\text { Screening of } \\
\text { Chinese films }\end{array}$ & 2.71 & 15.14 & 17.55 & 9.25 & 14.04 & 15.62 \\
$\begin{array}{l}\text { Construction } \\
\text { of cinemas in } \\
\text { cities }\end{array}$ & 0.79 & 5.25 & 1.42 & 1.07 & 0.3 & 1.7 \\
$\begin{array}{l}\text { Translation } \\
\text { and } \\
\text { production of } \\
\text { films about } \\
\text { ethnic groups }\end{array}$ & 1.81 & 1.89 & 1.89 & 1.89 & 1.89 & 1.89 \\
$\begin{array}{l}\text { Others } \\
\text { Total }\end{array}$ & & 6.33 & 35.37 & 25.57 & 4.57 & 11.51 & 31.99 \\
\hline
\end{tabular}

Source: Statistics extracted from the yearly budgets of SAPPRFT on its official website, http://www.sapprft.gov.cn/.

\section{B. The Effectiveness of the Incentive and Protective Policies}

While the incentive policies did guarantee the production of "main-stream" films, they discouraged the production of films belonging to different genres, which eventually resulted in a sharp decrease in film production. It is worth noting that the incentive and protective policies are meant to promote the production of "mainstream" films. However, reality shows that the direct subsidies cannot be credited for the exceptional success of domestic films as well as those of main-stream.

\section{A Burden for Private Companies}

The incentive policies are damaging the industry in two aspects. First, granted financial support is based on a subjective and flexible standard-the theme judged by a group of decision-makers-instead of advanced technology or scenario with outstanding artistic level. That the government is involved in the process 
of production conducts the industry toward the opposite direction of that of competitive advantages (Porter). Second, compared to their French counterparts that formed alliance to obtain financial aids from the government (Messerlin, "The French Audiovisual Policy" 9), the Chinese practitioners before reaching coalition burst into conflicts. National studios easily grab ample financial support with films of few earnings while private ones struggle to survive under the burden of the seat tax. In addition, the decreasing number of private studios, namely rivals in the industry, weakens its competitiveness.

The subsidy policies were not free of ill effects and drew their fair share of criticism. The most conspicuous criticism came from Feng Xiaogang, one of the most successful commercial film directors in China, whose films blend a sharp sense of humor with a wide array of topics and are extremely popular in China. At the time of the Chinese People's Political Consultative Conference in 2013, Feng openly declared his hostility towards the special fund during the session discussing how to "deepen the reforms in the cultural system and develop the cultural cause and industry." Feng suggested the suspension of the special fund which was perceived as being a hindrance for many movie-making studios, particularly the private ones. For example, the Huayi Brothers Media Group (for whom Feng has been working since 2004) had to pay 40 million Yuan (equivalent to US\$ 6.5 million) in 2012, which represented $50 \%$ of the net profit that year" (S. Zhang). Even for a prosperous group like Huayi Brothers, it clearly is a heavy financial burden.

\section{A Mediocre Output Concerning Domestic Film Production}

Direct subsidies organized and allocated by the government according to its needs seem to be less efficient than indirect ones. The wave of criticism that followed was mainly based on the fact that the incentive policies had allowed Chinese film producers to receive a great amount of financial help under the sole condition that their scenarios respect a set of ideological criteria. This means that if they stayed within line of core values set by the government then they were almost certain to be sponsored, regardless of the quality (or lack thereof) of their work. Once they drew the attention of decision-makers, the production was completed and the money spent. Producers in most cases do not have to worry about making quality films and about the revenue they generate as the commercial success of the movie is not contractually acquired by the special fund. This problematic situation thus dragged the film industry into a vicious cycle. Films are produced only in accordance with the government's preference instead of its audience. This diminished the market. In reaction to the reduced production, the market experienced a consequential downfall from 1996 to 2002. Figure 4 gives us a clear understanding about the 
evolution of the quantity of films produced. In 1996, the number of films dropped to only 110, compared to 153 films in 1993, 148 films in 1994 and 146 films in 1995. The data show a downward tendency that lasted up until 2002, when only 100 films were made.

As previously demonstrated, the incentive policy of governmental subsidies failed to encourage production from both public and private studios, and it was not until 2004 that the situation started to reverse itself (212 films produced in 2004 against 140 in 2003). The real breakthrough occurred in 2006 (with more than 300 films produced) when a large amount of private capitals began to flow into the industry, which should be another topic for further discussion.

\section{Film Production Since the Great Reform}

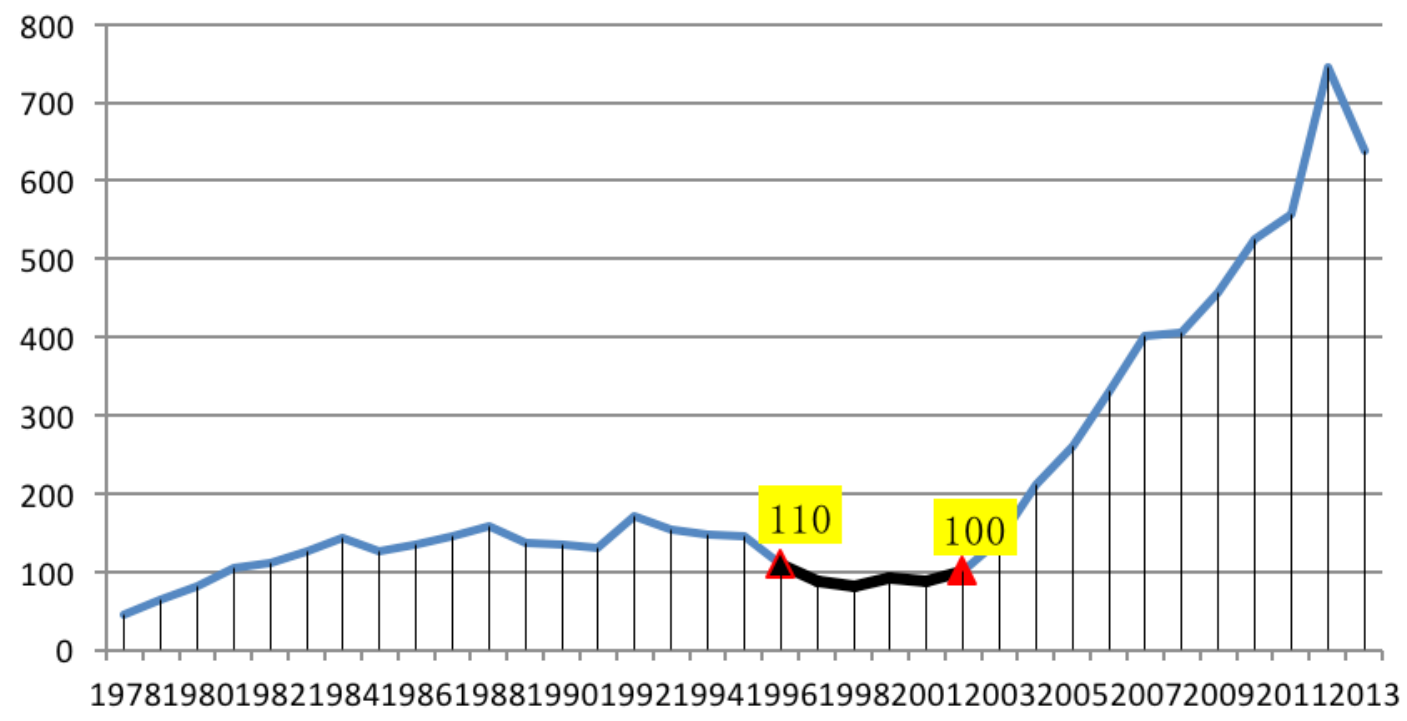

Figure 4: Output of the Films since the "Open and Reform"

Source: The National Bureau of Statistics of China, overviewed 15 $5^{\text {th }}$ May 2015: http://data.stats.gov.cn/workspace/index?a=q\&type=global\&dbcode=hgnd\&m= hgnd\&dimension=zb\&code=A0Q0B0O\&region=000000\&time=2013,2013. 


\section{The Failure of the "Going Out" Ambition}

Many argue that the government's export policies help industries to gain competitive advantages. On the basis of Porter's investigation, direct government intervention rarely manages to promote export ("The Competitive Advantage of Nations" 87). Financial success in the international markets is a marker of quality and would not only prove the efficiency of the producers but also set new standards for future productions. In contrast, achieving success only in the domestic market may only demonstrate that some monopoly enterprises benefit from advantages. As the Chinese film industry has been making incremental progress over the years, the export of its movies is now considered the best way to diffuse the government's wills and value and thus serves to improve the reputation of the country worldwide. However, it turns out this ambitious "going out" plan does not function so well.

Table 2: The Turnover Realized Overseas by Chinese Films (including Films from Hong Kong and Taiwan) from 2004 to 2017 (US\$ Millions)

\begin{tabular}{|l|l|l|l|l|l|l|l|l|l|l|l|l|}
\hline Year & 2004 & 2005 & 2006 & 2007 & 2008 & 2009 & 2010 & 2011 & 2012 & 2013 & 2016 & 2017 \\
\hline Income & 172 & 259 & 299 & 317 & 396 & 434 & 551 & 317 & 167 & 222 & 563 & 625 \\
\hline
\end{tabular}

Source: The data of 2014 and 2015 cannot be found. Luo Manfang, editor, Market of Films:

Domestic Operation and Exploitation Overseas, China Film Press, 2015, p. 389. Journal of China Films, 15 Aug. 2018, http://www.chinafilm.com/xwzx/3423.jhtml.

The statistics clearly indicate that Chinese films in foreign markets are still struggling for a breakthrough in recent years, demonstrating that a massive gap still exists between the products that the Chinese film industry has to offer ${ }^{7}$ and the demand of the foreign audience (which is perhaps partially due to some form of cultural differences). Starting in the year 2011, the revenue generated by Chinese films has experienced a drastic fall, and in 2012, it even fell back to the levels seen in the year of 2004. Some elements referring to this phenomenon need to be noted.

(1) Policies can play an important role in fixing the direction for an industry, but, how to improve the production by ameliorating its adaptability to totally different markets, and how to connect it to the distribution network abroad are two complex issues that members of the industry (who are now comfortably and safely making profits in a well-developed domestic market) need to figure out themselves, the public powers having reached their limits. 
(2) Implicit subsidies might be more important than explicit rewards, particularly when it involves the export of the film industry. Both the Special Fund and the 9550 Plan have been regarded by the decision-makers as a preferential access to the production and export of domestic films, but they are not as efficient as originally assumed. Implicit subsidies, such as the construction of infrastructures dedicated to the production of movies, combined with credits of advantageous interests from banks, as well as practical information and advanced technology shared between industry executives and officials, would be steps in the right direction.

\section{CONCLUSION}

Once the film industry was recognized as a manufacturing sector, the Chinese government removed administrative obstacles with the purpose of expanding this industry to the market that had been constricted before the reforms. The policies that are responsible for activating and enlarging the market did have some positive effects during the initial phase of reforms. However, this did not allow the industry to reach the desired economic and cultural breakthrough as they could not be adapted to a more liberal and open market.

This paper focused on the reforms that met government goals and experienced by the film industry as well as other industries such as the textile and electrical equipment industry. The decision-makers first sought to develop their capacity of manufacturing intermediate goods until final goods were being produced and an industrial system had been built. The authorities then endeavored to give more space to the private sector and to make the production more accessible from an administrative standpoint, with the purpose of reviving the industry while keeping its content under strict ideological control. The first stages of the reforms did create a rather favorable situation for the production of "intermediate goods" (mid-range films that told somewhat interesting stories with competent actors and directors albeit with a low-level post-production). In this sense and to Stiglitz's assumption, the government helped to create a stable political and financial environment for a relatively healthy market and directed investments in favor of making the industry one of the most lucrative sectors, profitable not only for domestic agents but also for foreign ones.

In the light of Porter's diamond model, competitive advantages indeed lie in the favorable economic environment institutionalized by the Chinese government. However, as a measure of direct intervention criticized by Porter, the incentive and protective policies completely failed to stimulate creativity and to advance technology at a higher level. As evidenced by the globalization of this industry, it 
is obvious that the "coming in" of foreign films and investments is more successful than the "going out" of domestic films. The latter requires producing films at international standards and its poor output suggests the failure of the superficial incentive and protective policies and that of a challenge facing the Chinese film producers.

More motivation and determination for deeper reforms are essential. This paper does not suggest further reforms. Rather, it concentrates on giving a clear image of how the industry improves itself in order to adapt to the market mechanism and how it heads to the process of globalization. The bottleneck encountered by the film industry concurring with the difficulties that other industries are facing in a period of economic transition might signal that classic economic wisdom in seeking solutions through factors of production (labor, land, infrastructure etc.) is no longer appropriate or adequate for sophisticated industries like the film industry, not to mention such an enormous and multivariant economic entity as China. 


\section{Notes}

1. The research and writing of this paper were initiated for the "ICAS 9 Conference" in 2015. Special thanks to Jimmyn Parc, Florian Deschanel, Adrien Deschanel, Zou Bo, Jeff Chen, and the three anonymous reviewers.

2. The Korean film industry was reclassified from "service" to "manufacturing" sector. Please see Jimmyn Parc, "Evaluating the effects of protectionism on the film industry: A case study analysis of Korea" 360 .

3. In January 1986, the Bureau of Film was transferred to the Department of Film and Television Broadcasting, which was in charge of the administration of the films and television programs. See Zhang Jiangyi, "Commercialization of Chinese Films in the New Era" 150.

4. Disney's famous film Lion King was imported in 1995 and generated US\$ 4.7 million in the box office. From then on, China was considered a potentially big market by the decision-makers of the company. However, the relationship between the latter and the Chinese Government deteriorated due to Disney's support of the film Kundun. In 1999, the then-president of Disney, Michael Eisner, went to China and was received by superior official Ding Guangen. After this visit, Disney agreed to distribute two Chinese films in North America and help a Chinese circus to tour in Europe. In the same years, Disney released Mulan in order to smooth out its relationship with China. Despite some ups and downs between the Chinese and American governments, Disney eventually won back the Chinese market.

5. For example, the villain in this film, the Mandarin, is a character inspired by stereotypical ancient Chinese official. This aspect was never criticized as heavily as Mulan was for distorting the image of the heroine. Consequently, it did not influence the release of the film.

6. Compared to $3 \%$ seat tax in Korea, the burden for most Chinese film producers is heavy. For a detailed analysis on the Korean film policies, see Jimmyn Parc, "The Effects of Protection in Cultural Industries: The Case of the Korean Film Policies" 618-633.

7. The data included the films coproduced with Hong Kong and Taiwan producers. 


\section{Works Cited}

Alesina, Alberto, and Dani Rodrik. "Distributive Politics and Economic Growth." Quarterly Journal of Economics, vol. 109, no. 2, 1994, pp. 465-490.

Amsden, Alice Hoffenberg. Asia's Next Giant: South Korea and Late Industrialization. Oxford UP, 1989.

--. "A Theory of Government Intervention in Late Industrialization." State and Market in Development, Synergy or Rivalry? edited by Louis Putterman and Dietrich Rueschemeyer, Lynne Rienner Publishers, 1992, pp. 53-84.

--. "Why Isn't the Whole World Experimenting with the East Asian Model to Develop? Review of the East Asian Miracle." World Development, vol. 22, no. 4, 1994, pp. 627-633.

Amsden, Alice Hoffenberg, and Ajit Singh. "The Optimal Degree of Competition and Dynamic Efficiency in Japan and Korea." European Economic Review, vol. 38, 1994, pp. 941-951.

Arrow, Kenneth Joseph, and Gérard Debreu. "Existence of an Equilibrium for a Competitive Economy." Econometrica, vol. 22, no. 3, 1954, pp. 265-29o.

The Association of Film Makers \& the Research Center of the Chinese Film Art Industry. The Report on the Research of the Film Industry. [in Chinese]. World Publishing Corporation, 2015.

Balassa, Bela. Policy Reforms in Developing Countries. Pergamon Press, 1977.

Greenwald, Bruce, Joseph Stiglitz and Andrew Weiss. "Informational Imperfections on the Capital Market and Macro-Economic Fluctuations," NBER (The National Bureau of Economic Research) Working Paper, Apr. 1984.

Haggard, Stephan. Pathways from the Periphery: The Politics of Growth in the Newly Industrialising Countries. Cornell UP, 1990.

Hellmann, Thomas, Kevin Murdock, and Joseph Stiglitz. "Financial Restraint: Towards a New Paradigm." The Role of Government in East Asian Economic Development, edited by Masahiko Aoki et al., Clarendon Press, 1997, pp. 163-207.

Hughes, Helen, editor. Achieving Industrialization in East Asia. Cambridge UP, 1988.

Krueger, Anne O. Liberalization Attempts and Consequences. Ballinger and National Bureau for Economic Research, 1978.

Lal, Deepak. The Poverty of Development Economics. The Institute of Economic Affairs, 1983.

Liu, Yang. "Politics First: Analysis on the Film Making Policies since Seventeen Years." [in Chinese]. Movie Literature, no. 14, 2009, pp. 8-11.

Messerlin, Patrick. “The French Audiovisual Policy: An Evaluation.” ECIPE, 2014. 15 Aug. $2018 \mathrm{http}$ ://ecipe.org/publications/patrick-messerlin-french-audiovisual-policyevaluation-english-version/. Accessed 2o Aug. 2018.

Messerlin, Patrick, and Jimmyn Parc. "The Effect of Screen Quotas and Subsidy Regime on Cultural Industry: A Case Study of French and Korean Film Industries." Journal of International Business and Economy, vol. 15, no. 2, 2014, pp. 57-73. 
Parc, Jimmyn. "Evaluating the Effects of Protectionism on the Film Industry: A Case Study Analysis of Korea." Handbook of State Aid for Film, edited by Paul Murschetz et al., Springer, 2018, pp. 349-366.

-.. "The Effects of Protection in Cultural Industries: The Case of the Korean Film Policies." The International Journal of Cultural Policy, vol. 23, no. 5, 2017, pp. 618-633.

Parc, Jimmyn, and Hwy-Chang Moon. "Korean Dramas and Films: Key Factors for Their International Competitiveness." Asian Journal of Social Science, vol. 41, 2013: 126-149.

Porter, Michael. The Competitive Advantage of Nations. Free Press, 1990.

--. "The Competitive Advantage of Nations." Harvard Business Review, March-April 1990, pp. 73-91.

Rodrik, Dani. "Co-ordination Failures and Government Policy: A Model with Applications to East Asia and Eastern Europe." Journal of International Economics, vol. 40, nos. 1-2, 1996, pp. 1-22.

--. "King Kong Meets Godzilla: The World Bank and the East Asian Miracle." CEPR Discussion Paper, 944, London, CEPR, 1994.

Rosen, Stanley. "Wolves Came: Hollywood and the Market of Chinese Films, 1994-20oo." [in Chinese]. The Compilation of the $1^{\text {st }}$ High-level Forum of Films and Television, 2001, pp. 336-360.

Singh, Ajit. "How Did East Asia Grow So Fast? Slow Progress towards an Analytical Consensus." Discussion Papers, 97, Geneva, UNCTAD, 1995.

--. "Openness and the Market Friendly Approach to Development: Learning the Right Lessons from Development Experience." World Development, vol. 22, no. 12, 1994, pp. $1811-1823$.

Stiglitz, Joseph. "Some Lessons from the East Asian Miracle." The World Bank Research Observer, vol. 11, no. 2, 1996, pp. 151-177.

--. "The State, the Market and Development." Mapping the Future of Development Economics, UNU WIDE $30^{\text {th }}$ Anniversary Conference, 2016, Helsinki. Keynote Speech.

Wade, Robert. "East Asia's Economic Success, Conflicting Perspectives, Partial Insights, Shaky Evidence." World Politics, vol. 44, no. 2, 1991, pp. 270-320.

--. Governing the Market: Economic Theory and the Role of Government in East Asian Industrialization. Princeton UP, 1990.

Wang, Gengnian. "Interview about the Development of the Chinese Film Industry in the 1990s." [in Chinese]. Contemporary Cinema, no. 1, 2001, pp. 4-10.

Zhang, Jiangyi. "Commercialization of Chinese films in the New Era." [in Chinese]. Film Art, no. 6, 2005, pp. 149-154.

Zhang, Shitao. "Feng Xiaogang Criticized the Special Fund." [in Chinese]. Chongqing Business, 3 Feb. 2013.

Zhou, Zhengbing. "Study on the Rationality of the Special Fund of the Film Industry." [in Chinese]. Film Art, no. 1, 2014, pp. 98-102. 